tions was one of the specialist journals, Internet and Higher Education, which had a rank of 3.56I for articles published in 2015. It was followed by Academic Medicine (2.202), and then three generic higher education journals which were very similarly ranked: Research in Higher Education (1.724), Higher Education (I.7I7), and the Review of Higher Education (I.703). Eight other journals had rankings in excess of I.o. The I3 highest ranked higher education journals include both the oldest established journals and some relatively new ones, the largest and some with a relatively small output, and seven that are international, three that are wholly American, and three that have split editorial boards.

It is to be expected that the number of higher education journals and their output of articles will continue to increase, as higher education continues to expand and interest in researching it grows. Print versions of journals will largely cease to exist, with virtually all publication and access online. The trend toward free, open access for an increasing number of journals and articles will continue, but well-established, high quality journals will likely still charge for access.

DOI: http://dx.doi.org/10.6oI7/ihe.20I8.94.10525

\section{The Vanishing Public Monopoly}

\section{Daniel C. Levy}

Daniel C. Levy is SUNY Distinguished Professor, Department of Educational Policy a Leadership, University at Albany, US. E-mail:dlevy@ albany.edu.

PROPHE (Program for Research on Private Higher Education) has a regular column in IHE.

$\mathrm{T}^{\text {he }}$ he spectacular expansion of private higher education (PHE) over now more than a half century is most often quantitatively depicted by rising raw enrollment, as well as by the rising private share of total enrollment. PHE now has more than 60 million students, a third of the world's total.

Private growth can be seen as largely complementary to public growth, as public enrollment growth has itself been unprecedented in its raw magnitude. But it is likewise valid to recognize a distinct casualty of private expansionthe near disappearance of public monopoly. By public monopoly we mean simply the absence of private institutions, whether they are proscribed by law or simply de facto nonexistent. The private institutions that break public monopoly can be nonprofit or for-profit; nonprofit is the more com- mon legal form globally, but both forms are growing and the boundaries between the two are often unclear.

Public monopoly was long a common norm. It reigned in Africa, the Arab region, Eastern Europe, and parts of Asia as recently as I989 and beyond. To be sure, it had dissipated earlier in Latin America, and many developed countries had long had anywhere from public near monopolies to substantial dual sectors. In mid-century, however, Communism brought a dramatic increase in public monopoly. There would also be subsequent scattered nationalizations of private sectors (e.g., Turkey, Pakistan).

\section{Vanishing Public Monopoly}

But there is no mistaking the global erosion of public monopoly in recent decades. The singular sudden tumbling came with Communism's I989 demise in all of Eastern Europe and much of Central Asia. And quite beyond that, each decade since I990 has continued to see the number of single-sector systems decline notably.

By 2000 , the main international database (UNESCO's)

\section{Private growth can be seen as largely complementary to public growth, as public enrollment growth has itself been unprecedented in its raw magnitude.}

showed only 39 countries with no private sector; by 2010 , 24. This is 24 out of I79 countries with available sectoral data. Yet the closer analysis of PROPHE's dataset shows that only 10 countries retain public monopoly: Algeria, Bhutan, Cuba, Djibouti, Eritrea, Greece, Luxembourg, Myanmar, Turkmenistan, and Uzbekistan.

Whereas the most important fact about this list is its small size, also striking is the absence of several particular countries. Communist China abandoned public monopoly in the early I980s, Communist Vietnam following suit thereafter, each now with roughly I5 percent private shares. (North Korea is not in the I79 country database but even it, however weirdly, ostensibly has an Evangelical private university.) Like China and Vietnam, Turkey allows PHE even while not allowing religious higher education. None of the populist-left regimes rising in Latin America since the I980s (Bolivia, Ecuador, Nicaragua, Venezuela) has even threatened to close PHE.

Furthermore, even the list of only io understates how limited public monopoly now is. First, three of the Io systems have fewer than Io, ooo total enrollments, and an additional three systems fewer than 300,000. Only Algeria, Cuba, Greece, and Myanmar retain public monopoly in 
sizeable systems. Second, several of the countries (Greece, Turkmenistan, Uzbekistan) allow an international or crossborder presence that is basically private. PHE registers there as zero enrollments simply because there is no state-recognized degree. Similarly, isolated domestic PHE programs exist without culminating in officially recognized degrees.

\section{The Tenuous Ten}

Moreover, several of the Io countries (e.g., Myanmar) already have active public discussion about private creation. Enabling legislation has sometimes been drafted. In Algeria, the largest of the systems, concrete proposals for private development have existed for a few years. Licensing applications are often precursors to actual PHE.

One salient political observation illuminates the present list, with implications for its persistence. The political regimes are markedly inclined to the left (however nebulous this term). True, we have seen that leftist orientation is no guarantee of public monopoly; the compatibility of leftist regimes with PHE is a striking sign of our times, of the contemporary precariousness of public monopoly. It does not, however, negate the reality that the group of io is far more to the left than the great bulk of the ${ }^{6} 6$ other countries.

Cuba is the clearest illustration. The only country in the Americas with a Communist regime is the only one with no PHE. Indeed, Cuba has so far not had any serious discussion of potential PHE. The last of the other traditionally identified 20 republics of Latin America to have broken public monopoly was Uruguay-in I985. Like Uruguay in its region, Greece long stood out in Europe for an atypically strong norm of statism in social welfare fields. Turkmenistan has been generally on the left among the "stans" (a similar generalization apt for Tajikistan, which only recently broke public monopoly). Myanmar is politically best characterized in its half-century of independence as repressive, but also with a socialist orientation. Algeria's public monopoly can be related not only to its French colonial tradition (generally less receptive than British colonial tradition to privateness), but also to its leftist leanings. The fact that so many other leftist regimes have broken public monopoly does not bode well for persisting public monopoly; nor do the incipient activities related to potential private creation in several of the countries. Broadly speaking, the contemporary era has a notable inclination toward privatization on various social fronts.

An independent perspective, less about political ideology than about organizational or world-system tendencies, might simply highlight how forms, once established, tend to spread. Public higher education once existed in only some countries before spreading to almost all; private sectors are now doing the same, not unlike the way public and then pri- vate sectors of higher education spread from one to several to almost all parts of individual countries. But whether or not the days of public monopoly are numbered, or whether they are ever to return, the main point here is not prediction. For one thing, prediction in private-public matters is fraught; when public monopoly was a strong norm, how many sage prognosticators identified the dimensions of the coming PHE surge? The main point here is to highlight a potent reality. Dual sectors are the dominant new norm, already spread to almost the entire world. The PHE surge is notable not just for its aggregate size but also very much for its near ubiquity. Public monopoly has become rare.

DOI: http://dx.doi.org/ıo.6oI7/ihe.20I8.94.10526

\section{Reconsidering Private Higher Education in Brazil}

\section{Targino de Araújo Filho}

Targino de Araújo Filho is professor, Federal University of São Carlos, Brazil, and currently a visiting scholar at the Centre for Higher Education Internationalisation (CHEI) at Università Cattolica del Sacro Cuore, Milan, Italy, supported by a CAPES-PGCI scholarship. E-mail: targino@ufscar.br.

$\mathrm{T}$ wo recent articles on Brazilian higher education in International Higher Education focused on private higher education: one presenting concerns about the growth of the for-profit segment of the private sector, and the other classifying this sector as the fuel of Brazilian economic growth. Although the private sector accounts for 76 percent of more than 8 million undergraduate enrollments-placing Brazil among the countries with the highest proportion of private enrollments worldwide-that consideration deserves a better analysis.

In fact, the expansion of higher education in Brazil has always occurred with the participation of the private sector, mostly composed of community, religious, and philanthropic higher education institutions (HEIs), and playing a role complementary to that of the public sector. Over time, the situation progressed and in I997, the private sector was responsible for 6r percent of enrollments. With the legalization of for-profit institutions, the system gained a new dynamic, resulting in 2,364 HEIs in 2015, among which 2,069 were private, with for-profit HEIs accounting for about 50 percent of enrollments. 